Bangladesh J. Sci. Res. 28(2): 103-111, 2015 (December)

\title{
DISEASE SEVERITY AND MYCOFLORA ASSOCIATED WITH ANTHRACNOSE ON LEAVES OF FIVE ANGIOSPERMS
}

\author{
Shamim Shamsi* and Najmun Naher ${ }^{1}$ \\ Department of Botany, University of Dhaka, Dhaka-1000, Bangladesh
}

\begin{abstract}
Severe anthracnose symptom was recorded on the leaves of five angiosperms during September to November, 2010. In total nine species of fungi belonging to four genera of the class deuteromycetes and a sterile fungus were found to be associated with the infected leaves of Abelmoschus esculentus (L.) Moench, Cucurbita maxima Duchesne, Datura metel L., Gossypium hirsutum L. and Vigna sinensis L. The associated fungi were Aspergillus flvaus Link, A. fumigatus Fresenius, A. nidulans (Eidam) G. Winter, A. niger van Tiegh, Cercospora sp., Colletotrichum capsici (Syd.) Butler \& Bisby, Colletotrichum dematium (Pers.) Grove, Colletotricum gloeosporioides (Penz.) Penz. and Sacc., Curvularia clavata Jain, and a sterile fungus.
\end{abstract}

Key words: Mycoflora, anthracnose, leaves, five angiosperm

\section{Introduction}

Anthracnose is a major and most common fungal disease of different angiospermic plants throughout the world. It can spread very quickly in warm $\left(80^{\circ} \mathrm{F}\right)$, wet weather, especially if air circulation is poor. This disease first appears as small, variously colored, circular spots on the older leaves, though it eventually spreads to younger leaves, stems, pods and fruits. The spots enlarge and merge, getting darker until the leaves drop off and the plant is defoliated and dies. In some cases symptoms appear as off-white, transparent lesions on leaves and other infected parts. Colletotrichum spp. are the causal organism of anthracnose disease (Douglas 2011).

Species of Colletotrichum produce spores in tiny, sunken, saucer-shaped fruiting bodies known as acervuli. Symptoms include sunken spots or lesions (blight) of various colours in leaves, stems, fruits, or flowers, and some infections form cankers on twigs and branches. Anthracnose causes the wilting, withering, and dying of tissues, though the severity of the infection depends on both the causative agent and the infected species and can range from mere unsightliness to death (Thurston 1998).

Many economically important crop plants, for example, cotton, cucurbits, tomato, banana, mango, onion and pepper are affected by the disease. Shade trees such as sycamore, ash, oaks, and maple are also susceptible. Lot of research had been carried out on anthracnose disease of economically important plants (Helene 1988, Thurston 1998, Latunde-Dada 1990 and Mukerji and Bhasin 1986). In Bangladesh a few research had been done on anthracnose disease of cotton and cow pea (Lutfunnessa and Shamsi 2011 and Shamsi et al. 2012). The present investigation

*Author for correspondence: <prof.shamsi@gmail.com>. ${ }^{1}$ Department of Botany, Life and Earth Science Group, National University, Gazipur-1704, Bangladesh. 
was undertaken to record the disease severity, pathogen and other associated fungi with anthracnose symptom of five angiosperms those were severely affected in the year of 2010 in some vegetable gardens of the Dhaka city.

\section{Materials and Methods}

Disease severity (DS) of anthracnose of leaf of five angiospermic plants viz. Abelmoschus esculentus (L.) Moench (Okra), Cucurbita maxima Duchesne (Pumpkin), Datura metel L. (Datura), Gossypium hirsutum L. (American cotton) and Vigna sinensis L. (Cowpea) was recorded following the scale stated by Ghos et al. (2009). These plants were grown at Botanical Garden of Curzon Hall Campus, Dhaka University and vegetable gardens near Mohakhali and Sobhanbag of Dhaka city during the month of January to December, 2010.

For visual estimation of disease severity, 0 - 9 point scale was used for rating all foliar disease studied (Ghos et al. 2009).

The associated fungi were isolated from symptomatic leaves following "Tissue Planting" method on PDA medium except Cercospora sp. was isolated following "Blotter” method.

Fifty plants were selected (ten from each angiosperm) randomly and 25 leaves from each plant were examined in each month.

Percentage of frequency of the occurrence of the fungal isolates was calculated following Spurr and Welty (1972):

$$
\% \text { frequency }=\frac{\text { No. of inocula from which a fungal isolate was obtained }}{\text { No. of inocula cultured }} \times 100
$$

The isolated fungi were purified following serial dilution technique and identified on the basis of morphological characteristics recorded under a compound microscope using standard key books (Barnett and Hunter 1998, Ellis 1971, 1976, Ellis and Ellis 1997, Sutton 1980).

Pathogenicity of the isolated fungi was tested following modified detached leaf assay technique (Azad and Shamsi 2011 and Shamsi et al. 2013).

\section{Results and Discussion}

Anthracnose symptom on the leaves of five angiosperms are presented in Plate 1A-E. The highest disease severity (DS) of anthracnose (score 9) was recorded on okra, cowpea and datura in the month of November. The highest DS (score 8) was recorded on American cotton and pumpkin in the same month. The minimum DS (score 1) was recorded on all the angiospermic plants studied in the month of April (Table 1). 

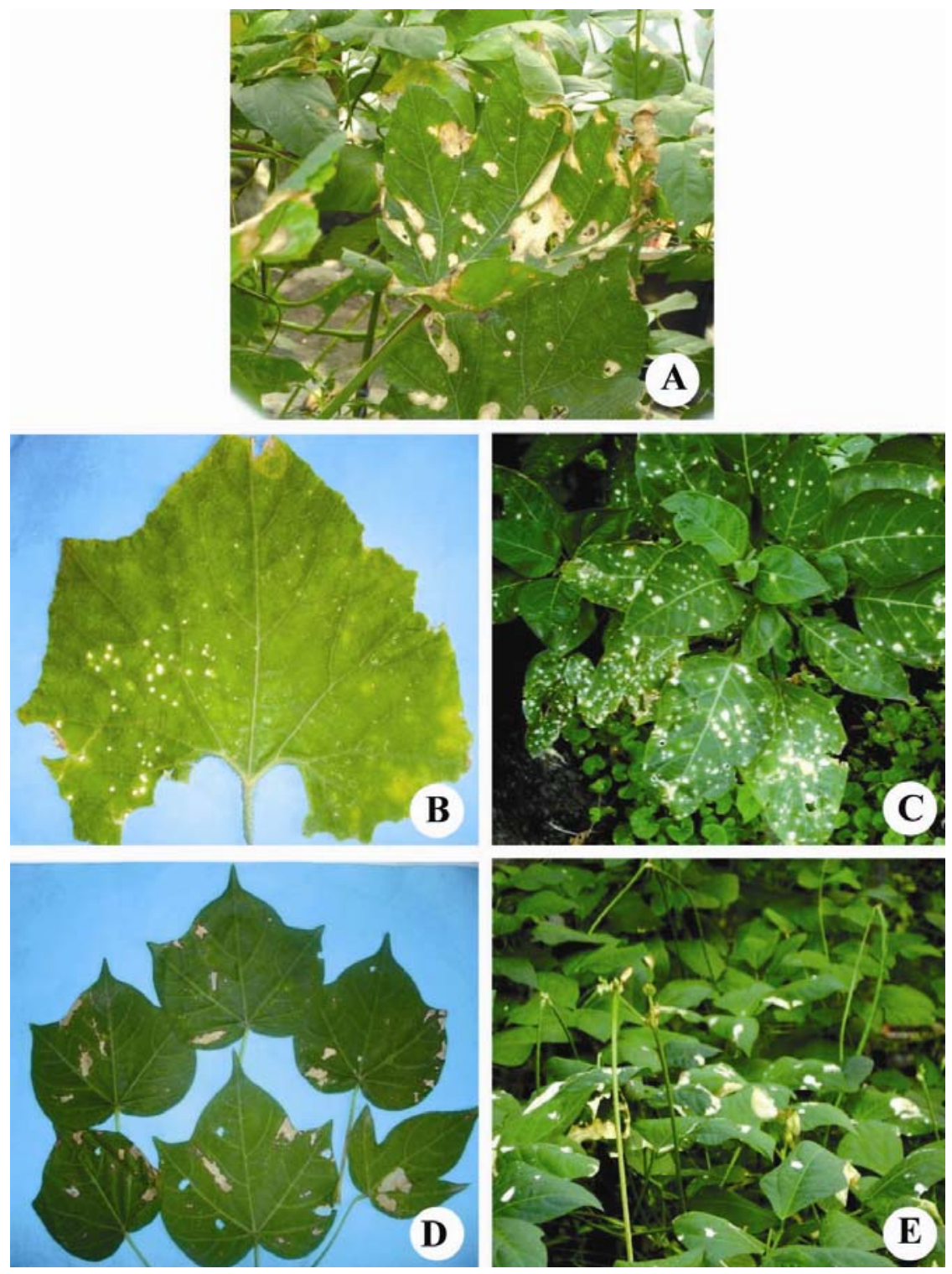

Plate 1. Anthracnose symptom on: (A) Abelmoschus esculentus (Okra); (B) Cucurbita maxima (Pumpkin);

(C) Datura metel (Datura); (D) Gossypium hirsutum and (E) Vigna sinensis (Cow pea).

In total, nine species of fungi, belonging to four genera of the class deuteromycetes and a sterile fungus was found to be associated with the infected leaves of okra, pumpkin, datura, A. cotton and cowpea showing anthracnose symptom. The associated fungi were Aspergillus flvaus, A. fumigatus, A. nidulans, A. niger, Cercospora sp., Colletotrichum capsici, C. dematium, C. gloeosporioides, Curvularia clavata and a sterile fungus (Table 2). 
Table 2 shows that from symptomatic leaves of okra, six species of fungi and a sterile fungus were isolated. Per cent frequency of occurrence of A. flavus was highest (46.66) followed by sterile fungus (40) and it was lowest in C. clavata (6.66). Per cent frequency of occurrence of $C$. capsici and C. gloeosporioides were 13.33 and 6.66, respectively.

Table 1. Disease severity of anthracnose recorded on five angiosperms during 2010.

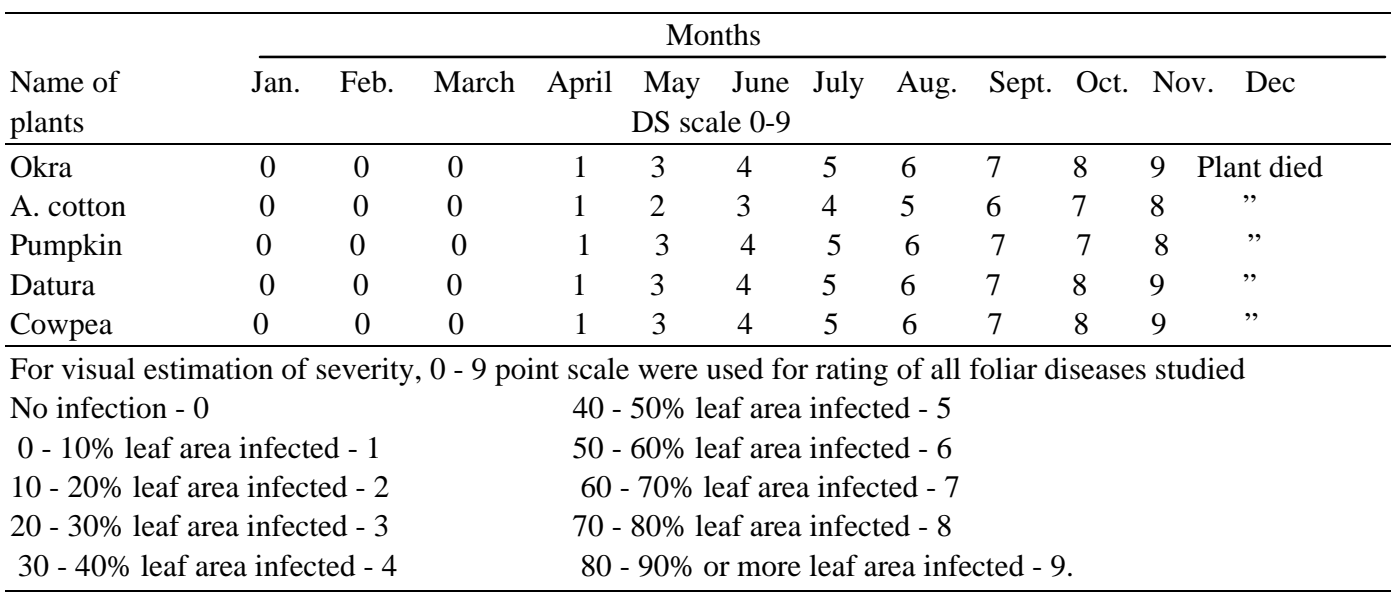

Table 2. Per cent frequency of associated fungi with anthracnose symptomatic leaves of five angiospermic plants.

\begin{tabular}{lccccc}
\hline \multirow{2}{*}{$\begin{array}{l}\text { Name of } \\
\text { fungi }\end{array}$} & \multicolumn{5}{c}{ Name of angiospermic host } \\
\cline { 2 - 6 } & Okra & A. cotton & Pumpkin & Datura & Cowpea \\
\hline Apergillus flavus & 46.66 & - & 46.66 & - & 26.66 \\
A. fumigatus & 6.70 & - & - & - & - \\
A. nidulans & 6.70 & - & - & - & - \\
A. niger & - & 0.5 & 6.66 & - & - \\
Cercospora sp. & - & - & 10.00 & - & - \\
Colletotrichum capsici & 13.33 & 20.00 & 33.33 & 41.66 & 60.00 \\
C. dematium & - & 30.00 & - & - & - \\
C. gloeosporioides & 6.66 & 20.00 & 60.00 & 41.66 & 40.00 \\
Curvularia clavata & 6.66 & 52.00 & 13.33 & 16.66 & 20.00 \\
Sterile fungus & 40.00 & 20.00 & 6.66 & 25.00 & 6.66 \\
\hline
\end{tabular}

- = Not found.

Mukerji and Bhasin (1986) reported Colletotrichum capsici, C. gloeosporioides and C. hibisci from okra.

In Bangladesh 16 diseases of okra have been recorded, among them anthracnose is one of the major disease. Anam et al. (2002) reported five seed borne fungal diseases in okra field. Foot and Root rot, Anthracnose and die-back, Cercospora leaf spot, Corynespora leaf spot and blight 
caused by Fusarium oxysporum, Colletotrichum dematium, Cercospora abelmoschi, Corynespora cassicola and Macrophomina phaseolina, respectively.

Table 2 shows that four species of fungi and one sterile isolate were associated with symptomatic leaves of American cotton (G. hirsutum). Percentage frequency of occurrence of $C$. clavata was highest (52) followed by C. dematium (30), C. gloeosporioides and a sterile isolate (20). Lowest per cent frequency of occurrence was recorded in A. niger (5).

The family Malvaceae is large and consists of important agricultural crops (cotton, okra, kenaf etc.). The family, as a whole is affected by several anthracnose diseases. Three main species of Colletotrichum have been recognized as the causal agents of anthracnose, Colletotrichum gossypii, C. malvarum and C. gloeosporioides. Colletotrichum gossypii is the main causal organism of anthracnose of cotton (Bailey et al.1996). Mukerji and Bhasin (1986) reported C. capsci and $C$. indicum on $G$. hirsutum from India.

Six species of fungi and a sterile isolate were associated with symptomatic leaves of pumpkin (C. maxima). Per cent frequency of association of C. gloeosporioides was highest (60) followed by A. flavus (46.66), C. capsici (33.33), C. clavata (13.33) and Cercospora sp. (10). Lowest per cent frequency of association was recorded in A. niger and a sterile fungus (6.66) (Table 2).

Anthracnose is a common fungal disease of pumpkin in fields, greenhouses, and high tunnels. The disease can develop on all above ground parts of pumpkin plants. In pumpkin anthracnose is caused by the fungus Glomerella lagenarium (Colletotrichum orbiculare). The symptoms of anthracnose vary somewhat on different hosts. On cucumber leaves the spots start as water soaked areas and expand into brown spots which are roughly circular (Wasilwa et al. 1993). Mukerji and Bhasin (1986) reported C. capsici, C. lagenarium and C. orbiculare on C. maxima from India.

Table 2 shows that three species of fungi and one sterile isolate were associated with symptomatic leaves of datura. Frequency percentage of association of C. capsici and C. gloeosporioides were highest (41.66) followed by sterile fungus (25). Lowest frequency percentage of association was recorded in C. clavata (16.66). Mukerji and Bhasin (1986) also reported C. capsici on Datura spp. from India.

In Bangladesh three species of fungi (Colletotrichum sp., Pseudocercospora sp. and Trichoderma sp.) found to be associated with anthracnose symptom of Datura metel and Vigna catjang (Shamsi et al. 2012).

Table 2 also shows that from anthracnose symptomatic leaves of cowpea ( $V$. sinensis) four species of fungi and one sterile isolate were isolated. Per cent frequency of association of $C$. capsici was the highest (60) followed by C. gloeosporioides (40), A. flavus (26.66) and A. fumigatus (20). Lowest per cent frequency of association was recorded in sterile fungus (6.66).

The major fungal pathogen of cowpea crop was reported as the Colletotrichum destructivum. (Akinbode and Ikotun 2008, Emechebe and Lagoke 2002). Latunde-Dada (1990) reported anthracnose disease of five cowpea cultivars: Farin Juda-C, Ife Brown, Market Brown, IT82E-60 
and TVX 3236 caused by C. lindemuthianum. Mukerji and Basin (1986) also reported C. capsci, Colletotrichum dematium and $C$. lindemutheanum on $V$. sinensis from India.

Difference may occur in result of the experiment due to variation of time, place/locality, weather conditions, plant varieties used in the experiment and ability of the fungi to attack the specific plants.

\section{Details on the isolated pathogens are as follows}

1. Colletotrichum capsici (Syd.) Batler \& Bisby

(Plate 2A - B)

Colonies grayish. Hyphae brown, septate, branched, conidiophores are $3-45 \times 2-6 \mu \mathrm{m}$, hyaline, cylindrical, unicellular or septate. Setae dark brown. 3 - 4 septate, 61 - $75 \mu \mathrm{m} \times 3.5-4.0$ $\mu \mathrm{m}$. Conidiogenous cells are $6-10 \mu \mathrm{m} \times 2.5-4 \mu \mathrm{m}$ wide, hyaline, ellipsoidal to subglobose, conidia are $17-24 \mu \mathrm{m} \times 2.5-3.5 \mu \mathrm{m}$, one-celled, gluttulate, hyaline, fusiform with both ends pointed.

Specimens examined: Isolated from infected leaves of Vigna sinensis. Sobhanbag, Dhaka. S. Shamsi, 30 38, 30 June, 2010.

2. Colletotrichum dematium (Pers.) Grove

(Plate 2C - D)

Colonies dark, cottony, with black shinning aervuli. Hyphae brown, septate, branched superficial. Setae dark brown. $3-4$ septate, $62-72 \mu \mathrm{m} \times 3.5-4.0 \mu \mathrm{m}$. Conidiophores pale brown, $\quad 14-22 \times 1.8-2.7 \mu \mathrm{m}$. Conidia solitary, curved, hyaline, $20-34 \times 3-4 \mu \mathrm{m}$. Appressorium present, brown, small irregular, 4.8 - $6.0 \times 4.0-48 \mu \mathrm{m}$.

Specimens examined: Isolated from infected leaves of cotton varieties CB6, Botanic garden, Dhaka University, Dhaka. S. Shamsi, 30 48, 13 July, 2010.

3. Colletotrichum gloeosporioides (Penz.) Penz. and Sacc.

(Plate 2E-F)

Colonies grayish. Hyphae brown, septate, branched superficial. Setae dark brown. 3 - 4 septate, 59 - $72 \mu \mathrm{m} \times 3.5-4.0 \mu \mathrm{m}$. Conidia are straight, obtuse at the apex, (6.2) 11 - 27 to 2.2 3.4 (5) um. Appressoria are 8.4 - 11.2 to 4.2 - 8.0 um, clavate or irregular, sometimes becoming complex.

Specimens examined: Isolated from infected leaves of cotton varieties CB6, Botanic garden, Dhaka University, Dhaka. N. Naher, 75, 23 July, 2010.

Present results indicate that per cent frequency of association of anthracnose pathogen $C$. capsici was the highest (60) in $V$. sinensis followed by 41.66 and 33.33 in D. metel and $C$. maxima, respectively. Per cent frequency of association of the fungus was the lowest 13.33 in $A$. esculentus. Per cent frequency of association C. dematium was 30 in G. hirsutum. Per cent frequency of association of $C$. gloeosporioides was the highest (60) in C. maxima followed by 
41.66, 40.00 and 20.00 in D. metel, V. Sinensis and cotton, respectively. Per cent frequency of association of the fungus was the lowest 6.66 in A. esculentus.
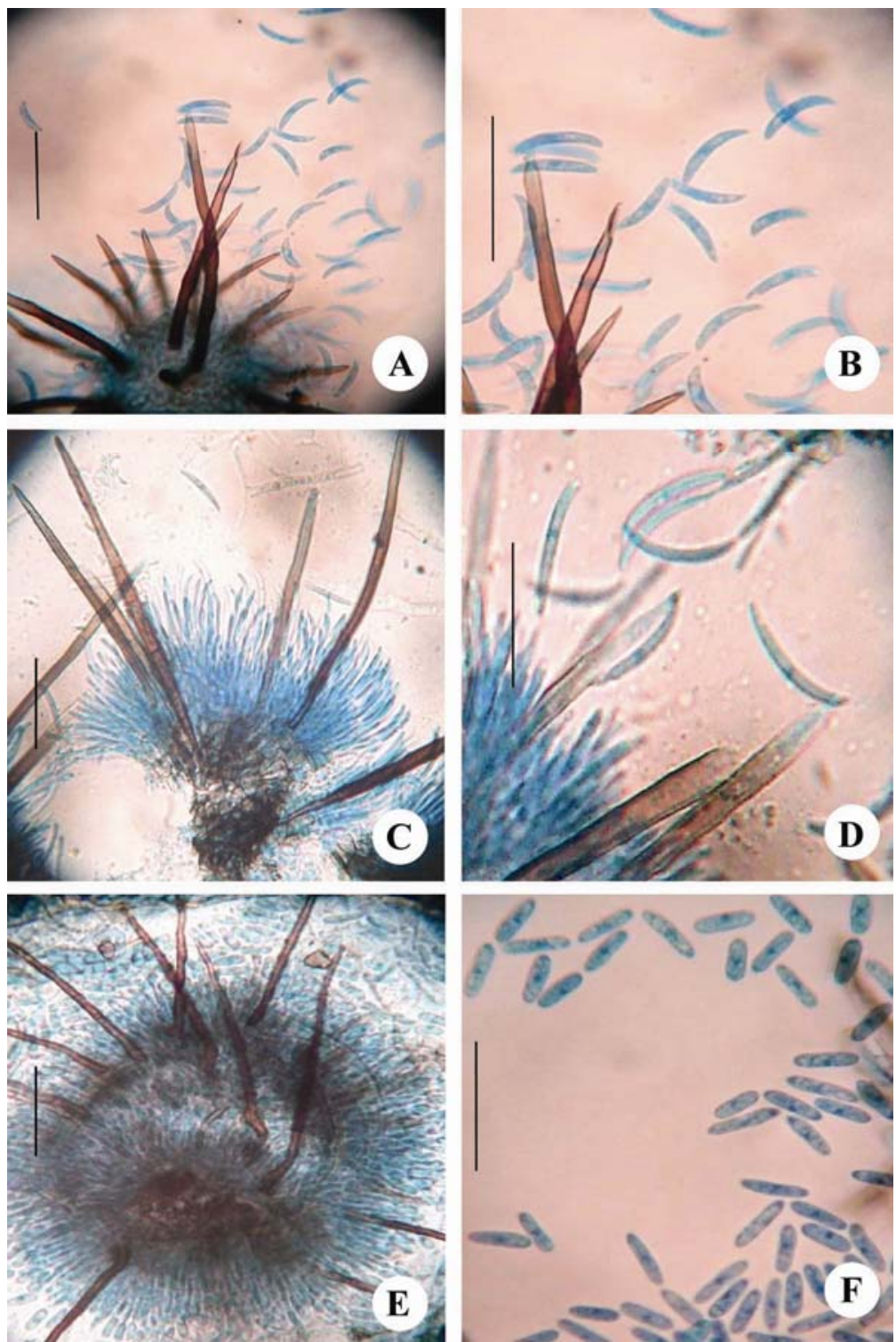

Plate. 2. Acervulus of: (A) Colletotrichum capsici; (B) Conidia and setae of Colletotrichum capsici;

(C) Acervulus of Colletotrichum dematium; (D) Conidia and setae of Colletotrichum dematium; (E) Acervulus of C. gloeosporioides and (F) Conidia of C. gloeosporioides. (Bar $=50 \mu \mathrm{m})$. 
Pathogenicity test following modified detached leaf technique revealed that Colletotrichum capsici was pathogenic to A. esculentus, C. maxima, D. metel, G. gossypium and V. sinensis. Colletotichum dematium was pathogenic to G. gossypium and C. gloeosporioides was pathogenic to A. esculentus, C. maxima, D. metel, G. gossypium and V. sinensis.

\section{References}

Akinbode, A. O. and T. Ikotum. 2008. Evaluation of some bioagents and botanicals in in vitro control of Colletotrichum destructum. Afr. J. Biotech. 7(7): 868-872.

Anam, M. K., G. M. Fakir, K. M. Khalequuzzaman, M. M. Hoque, and A. Rahman. 2002. Effect of seed treatment on the incidence of seed-borne diseases of Okra. Plant Pathol. Journal 1(1): 1-3.

Azad, R. and S. Shamsi. 2011. Identification and pathogenic potentiality of fungi associated with Huttuyania cordata Thunb. Dhaka Univ. J. Biol. Sci. 20(2): 131-138.

Bailey, J. A., C. Nash, L. W. Morgan, R. J. O, Connel and D. O. Beest. 1996. Molecular taxonomy of Colletotrichum species causing Anthracnose on Malvaceae. Phytppathology 86: 1076-1084.

Barnett, H. L. and B. B. Hunter. 1998. Illustrated Genera of Imperfect Fungi. APS Press, The American Phytopathological Society. St. Paul, Minnesota. USA. pp. 218.

Douglas, M. S. 2011. Anthracnose diseases of Trees. The Connecticut Agricultural Experiment Station. USA. www.ct/caes. pp. 1-7.

Ellis, M. B. 1971. Dematiaceous hyphomycetes. The Commonwealth Mycological Institute, England, pp. 608.

Ellis, M. B. 1976. More Dematiaceous hyphomycetes. The Commonwealth Mycological Institute, England. pp. 507.

Ellis, M. B. and J. P. Ellis. 1997. Microfungi on Land plants: An Identification Handbook. New enlarged edition. The Richmond Publishing Company Ltd. England. 868 pp.

Emechebe, A. M. and S.T.O. Lagoke,. 2002. Recent Advances in Research on Cowpea Diseases in Challenges and Opportunities for Enhancing Sustainable Cowpea Production. Proceeding of the World Cowpea Conference III, the International Institute of Tropical Agriculture (IITA), Ibadan, 4-8 September 2000. pp. 94-123.

Ghosh, P. P., D. Mandal, S. Laha and M. K. Dasgupta. 2009. Dynamics and severity model in managing fungal diseases. The Journal of Pl. Ptotec. Sci. 1(1): 55-59.

Helene R. D. 1988. Bean Anthracnose. An online fact sheet (htm).State. Cornell University. New York. http://vegetable onlineppath.cornell.edu/ Page 729.40. 6-1988.

Latunde-Dada, A. O. 1990. Assessment of anthracnose disease in some cultivars of cowpea (Vigna unguiculata) Caused by Colletotrichum lindemuthianum. J. of Phytopathol. 130(2): 147-156.

Latunde-Dada, A. O., R. J. O’Connell, C. Nasa, R. J. Pring,, J. A. Lucas and J. A. Bailey. 1996. Infection process and identity of the hemibiotrophic anthracnose fungus Colletotrichum destructivum from cowpea (Vigna unguiculata). Mycological Research 100:1133-1141.

Lutfunnessa, R. J. F. and S. Shamsi. 2011. Fungal diseases of cotton plant - Gossypium hirsutum L. Bangladesh. Dhaka Univ. J. Biol. Sci. 20(2): 139-146.

Mukerji, K. G. and J. Bhasin. 1986. Plant diseases of India: A source book. Tatta Mc.Grew-Hill Publishing Company Ltd. New Delhi. 468 pp. 
Shamsi S., N. Naher and R. Haq. 2012. Fungi as biocontrol agents in nature: Interaction of fungi on phylloplane of Datura metel L. and Vigna catjang L. Bangladesh J. Agri. Res. 37 (3): 537-541.

Shamsi, S., P. Chowdhury and N. Naher. 2013. Mycoflora associated with the leaves of Senna alata (L.) Roxb. J. Bangladesh Acad. Sci. 37(2): 249-252.

Spurr, H. W. Jr. and R. E. Welty, 1972. Incidence of tobacco leaf mycoflora in relation to brown spot disease and fungicidal treatment. Phytopathology 62: 916-920.

Sutton, B. C. 1980. The Coelomycetes. Fungi Imperfecti with Pycnidia Acervuli and Stromata. Commonwealth Mycological Institute. England. pp. 696.

Thurston, D. 1998. Tropical Plant Diseases. (2 ${ }^{\text {nd }}$ edition). APS Press. The American Phytopathological Society. St. Paul, Minnesota, USA. pp. 208.

Wasilwa, L. A., J. C. Correll, T. E. Morclock and R. E. McNew. 1993. Re-examination of race of cucurbit anthracnose pathogen Colletotrichum orbiculare. Phytopathology 83: 1190- 1198.

(Manuscript received on May 31, 2015; revised on November 25, 2015) 